\title{
Research on the Countermeasures Against the Consumption Risks of College Students Based on the Campus Loan Platform
}

\author{
Jinli Zhang, Zhen Li, Chaorui He, Xinyue Wang
}

Jiangsu Food and Pharmaceutical College, Huai’an 223005, Jiangsu, China. E-mail: Lz502502@163.com

Fund Project: The phased research results of the general project of the Jiangsu Provincial Department of Education Philosophy and Social Science Fund "Research on Countermeasures against Consumption Risks of College Students Based on the Campus Loan Platform" (No. 2018SJA1661).

\begin{abstract}
In recent years, online credit platforms have emerged one after another. With the continuous development of China's "Internet +", the Internet finance industry has shown explosive growth, and P2P peer-to-peer loans have emerged. Some peerto-peer credit platforms have expanded their business to universities, targeting college students with high consumer demand and little social experience, which has seriously affected the study and life of college students and brought serious negative impacts to society. Universities must strengthen the risk management of "campus loans" and take effective preventive measures. The risks of campus loans include loan risks, guarantee risks, default risks, etc. The causes of these risks are the lack of legal and financial knowledge of college students, the deviation of consumption concepts, and the publicity and risk assessment errors of campus loans. Through an in-depth analysis of the risks of college students' campus loans, this article puts forward feasible preventive measures that are conducive to ensuring the personal and property safety of college students.
\end{abstract}

Keywords: Campus Loan; Consumption Risk; Preventive Countermeasures; College Students' Consumption Outlook

In the era of the rapid development of the Internet, Internet finance has also achieved rapid development with the help of its technology. It has even penetrated into university campuses. Due to its simple procedures and characteristics of handling, many college students have applied for campus online loans for various reasons. Under the online lending service, while college students are gaining benefits, due to insufficient laws and regulations and weak government supervision, campus online loan business often generates excessive interest, personal information leakage, suspected fraud, and other chaos, which has led to many students Unable to pay off the loans, vicious incidents such as naked strip incidents and coerced gambling eventually occurred. The disorderly development of these incidents has caused serious threats to the safety of college campuses and the safety of college students' lives and property. If they are allowed to develop recklessly, society will stability and national tranquility will also be more or less negatively affected.

\section{Analysis of the reasons for the connection between college students and "campus loans"}

"Campus loan" is essentially a form of online lending aimed at students. Its platform and transaction methods are similar to ordinary lending, and transactions are conducted through the Internet. However, online financial tools generally have the characteristics of extreme penetration and high concealment. Under the premise that my country's financial risk prevention mechanism is not perfect, the supervision of the online financial market is limited, and illegal financial institutions are rampant. Their criminal claws naturally extend to the inexperienced and rigid a group of college students who have recently left home. The main reasons for the connection between college students and "campus loans" are as follows.

Copyright $(2020$ Jinli Zhang et al.

doi: 10.18686/ahe.v4i10.2940

This is an open-access article distributed under the terms of the Creative Commons Attribution Non-Commercial License (http://creativecommons. org/licenses/by-nc/4.0/), which permits unrestricted non-commercial use, distribution, and reproduction in any medium, provided the original work is properly cited. 


\subsection{Lack of relevant professional knowledge among college students}

It is not ruled out that college students borrowing on campus for reasonable reasons or for emergency reasons. However, due to the lack of legal and financial-related professional knowledge and vague knowledge, their legal awareness is weak, and they encounter unreasonable phenomena in campus loans such as usury or hidden fees, either there is no identification, or lack of social experience can only swallow, and what is more will evolve into borrowing new loans to repay old loans, the amount of loans is getting bigger and bigger like a snowball.

\subsection{Weak personal protection awareness}

Since college students do not go deep into the world, they can easily trust others, so they do not know how to save personal information. Other personal information, such as ID cards, student IDs, and Xuexin.com materials, is not very clear about its importance, so it is easy to lend it to others, or sign as a guarantor to assume responsibility for the guarantee. When college students lack self-protection awareness, they are not sufficiently vigilant about strangers and strange wealth, and they will be deceived.

\subsection{Immature consumption concepts}

Many college students left home for the first time because they went to university in other places. It can also be said that they left their parents' control and entered a colorful university campus. They also encountered a mixed society for the first time, and they had relatively more free time. Many students in such an environment, the desire for comparison and enjoyment has arisen. After the monthly living expenses given by parents can no longer guarantee their consumer psychology and vanity, the immature consumption concept of college students causes them to sink into campus loans and cannot withdraw.

\subsection{Campus loan platform supervision and risk assessment issues}

The lending business in compliance with laws and regulations is not illegal in itself, but some campus loan platforms have added a lot of false propaganda factors to their business in order to attract college students' customers, and the loan requirements have been repeatedly lowered, so that college students can easily repay the illusion, coupled with the deviation of college students' risk assessment of campus loans, and the ignorance of the serious consequences of campus loans, will only be hurt by college students and their families. The campus loan platform takes advantage of the fact that college students have family members as backing, and almost does not review the ability of college students to repay. Such operations are prone to produce bad loans.

\subsection{School education issues}

In recent years, social news about "campus loans" has frequently appeared in the newspapers. College students commit suicide and commit crimes because of campus loans. However, such incidents have continued to occur frequently in recent years, and even "naked loans" and "8 days a day" have occurred. Bad incidents such as "every change of 80 , 000 " show that when the incident first happened, the school did not pay attention to relevant education for students, nor did it conduct loan investigation and special education for college students, which led to many similar cases in many universities. Incurred huge debts, suffered personal threats due to inability to repay loans, etc.

\section{The harm of "campus loan" to college students}

Loan companies extend their business hands into the campus to provide student loans, entrepreneurial loans, consumer loans and other businesses for college students. At the same time, it has spawned social problems such as loan sharks, violent collection of late fees, fraudulent sales promotion, as well as student information leakage and identity fraud. Problems are unfavorable to students, such as the use and credit information being affected. Initially, in order to attract students to apply for campus loan business, many campus loan platforms adopted a method of lowering the threshold to entice students to open the business. However, because of their inexperience in the world and insufficient knowledge, they were unable to see the usury nature of campus loans. Many students were unable to threats and extreme behaviors caused by timely repayment.

University campus and university life should help students shape their outlook on life and values, and allow them to pursue their ideals in a good environment. However, after applying for campus loans, some college students have wrong values, let themselves go, and generate high consumption and excitement. Consumption; after being unable to repay the debt, psychological trauma is caused by the extreme measures of the debt collector. After being exposed to campus loans, 
college students have already developed negative psychological and behavioral factors, and their time, energy, and personal information have been affected. Even unable to complete their studies smoothly, this vicious circle has an adverse effect on the life process of college students.

From the perspective of social stability, after college students have overdue repayments, illegal campus loan platforms will take extreme measures to collect debts, harass the students themselves and their surrounding classmates, teachers, relatives and friends, etc., which has a negative impact on social stability and public safety influences. From the perspective of campus life, the small advertisements on campus loans can be said to be pervasive. Small advertisements have appeared on the school bulletin board, cafeteria dining table, and toilet door. The impact on students should not be underestimated. On the one hand, they disrupt the normal study and life of students. On the one hand, under the influence of campus loans, some students skip classes and work to make money to repay loans, resulting in lower grades. Such negative and negative effects are all harm to the people and things around the college student computer.

\section{List of consumer risk prevention measures}

\subsection{From the perspective of college students}

From the perspective of college students, there are three points that need to be done. The first is to enhance legal awareness. After studying, learn about contract law, tort law and other related knowledge, sort out the concepts and principles of guarantee, breach of contract, and tort, and understand the fraud that college students are easy to commit. Charges, raise awareness of risks, and avoid exposure to illegal and criminal matters; the second is to understand financial knowledge, and understanding of basic financial terms will help universities to physiologically judge borrowing-related issues and avoid the risks brought by blind borrowing; third is Read and think diligently, cultivate the correct way of thinking and judgment.

\subsection{From the perspective of school education}

As for schools, it is necessary to take into account the real poor students and solve their financial problems through the aid system, such as scholarships, bursaries, work-study programs, etc., so that students can get help through legal channels, instead of seeking help and eventually going to campus loans. We should strengthen the education of students, face up to campus loans, and publicize the hazards and risks of campus loans through the school's voice platform such as WeChat public account, class meetings and other channels. At the same time, we should pay attention to the mental health education of college students and correctly guide students' consumption views. Third, through the renovation of the advertising platform on campus, eliminate the bombing of advertisements that are overwhelming campus loans, and return students to a quiet campus.

\subsection{From the perspective of society and government}

Internet finance is developing rapidly, and it is also an emerging industry. The rules and regulations of relevant state departments for online loans still need to be improved. Campus loan risks are not only risks encountered by college students, but also social and legal risks such as irregular platforms and insufficient supervision. The laws and regulations related to campus loans and P2P network lending in my country can effectively regulate the network Lending institutions, offline lending, false propaganda, and illegal lending create conditions for the stable development of society.

\section{Conclusion}

College students' consumption views can be guided and reshaped. If deviations occur, they can be corrected through school education and social impact, to enhance college students' cognitive level, reduce the poison of campus loans on college campuses, and create a positive effect for society and students.

\section{References}

1. Wang Y, Yu N. Thoughts on the consumption outlook of contemporary college students triggered by "campus loans". Leadership Science Forum 2017; 000(011): 65-66.

2. Chen X. Analysis of the status quo of college students' campus loans and preventive strategies. Youth 2019; 000(009): 146-147. 